OPEN ACCESS

UNIVERSITY OF THE

WEST of SCOTLAND

UWS Academic Portal

\title{
International development ideology and two tourism policies of Nepal
}

Bhandari, Kalyan

Published in:

Environment and Planning C: Politics and Space

DOI:

$10.1177 / 2399654418788865$

Published: 01/05/2019

Document Version

Peer reviewed version

Link to publication on the UWS Academic Portal

Citation for published version (APA):

Bhandari, K. (2019). International development ideology and two tourism policies of Nepal. Environment and Planning C: Politics and Space, 37(3), 558-576. https://doi.org/10.1177/2399654418788865

\section{General rights}

Copyright and moral rights for the publications made accessible in the UWS Academic Portal are retained by the authors and/or other copyright owners and it is a condition of accessing publications that users recognise and abide by the legal requirements associated with these rights.

Take down policy

If you believe that this document breaches copyright please contact pure@uws.ac.uk providing details, and we will remove access to the work immediately and investigate your claim. 


\title{
International development ideology and two tourism policies of Nepal
}

\begin{abstract}
This paper examines the role of development discourse in Nepal's tourism policy. In Nepal, tourism is an important part of development activity that is driven by international development partners. Since the ideology that drives the international agencies has undergone a huge transformation in the last 25 years, it would be useful to see how such changes are reflected in the tourism public policy of Nepal. Data include analysis of two tourism policies, other documentary sources and interviews with eminent tourism experts to compare the two tourism policies when international development 'thinking' was different. The findings show that seemingly 'tourism' policies are the outcome of domestic political contexts, that they are not outwith the scope of international development ideology advanced by development partners. The paper makes a useful contribution to understanding the role of international development ideology in the tourism policy-making of a developing country.
\end{abstract}

Keywords: policy making, ideology, tourism, developing countries, Nepal 


\section{International development ideology and two tourism policies of Nepal}

\section{Introduction}

Public policies are the outcome of political processes (Hall and Jenkins, 1995; Dredge and Jenkins, 2003, a,b) and are usually formulated to represent the political ideology of the party in power (Getz, 2012). Political parties take different approaches to the economy, social development and external relations. Their understanding of culture, leisure, sports and tourism is based on their value sets or party positions, and once in power they execute their vision through public policies. However, in this age of globalisation, political parties and nation states are not absolutely independent and policies are shaped by a considerable number of other influences which originate beyond national territory. As a form of transnational exchange, the international element is undoubtedly prominent in tourism. In the context of developing countries, economic ideology is also informed by international development 'discourse' that plays a large part in shaping their public policies. However, existing literature on tourism's public policy extensively treats tourism policy as a national issue and pays little attention to the ideology of international development agencies and their role in national tourism policy.

There have been two major strands of development thinking in the last 25 years that have largely influenced the policy context in developing countries: i) neo-liberalism and ii) neostructuralism. Neoliberalism was encapsulated in the 1980s in the form of structural adjustment programmes that advocated trade liberalisation, privatisation and market policies (see Bitar,1988). However, the neo-liberal approach was modified during the later 1990s to take account of the new economic, financial and external and internal factors, and replaced with neo-structuralism, which proposes promoting the development of institutional, social, human and knowledge capital so as to strengthen endogenous growth in countries of the periphery (ECLAC, 2002).

The fundamental difference between the two approaches is in the understanding of the role of the state in development. The neo-liberal approach sought to dismantle the apparatus of statecontrolled economic institutions and regulations; for example, state-owned assets were privatized, budgets balanced, independent central banks brought inflation under control and liberated money markets and taxes on consumption rather than income tax were imposed 
(Murray and Overtone, 2011; Harvey, 2005). Poverty elimination was not an explicit concern; rather, it was believed that aggregate economic growth should be promoted and that this would eventually filter down to the poor, whereas according to the neo-structural approach the state must intervene to ensure that peripheral economies move beyond resource dependent development and add value to their products (Murray and Overton, 2011). Neostructuralism argues that forging a successful economy is dependent on the creation of a democratic participatory society where harmony and cohesion are paramount. Thus the state has a role not only in actively intervening to create competitive advantage but also as a body that facilitates belonging (Murray and Overtone, 2011). In this sense, neo-structuralism seeks to restore the balance of the relationship between society and the state (Murray and Pastor, 2008), and allows centre-left political groups to offer much to all sectors and interests in society; for example, business and the capitalist elite are not threatened, the marginalised are promised a share and external powers are happy as markets remain open (Murray and Overtone, 2011). Such a change in development thinking was bound to make a huge impact on the public policies of aid-recipient countries because these approaches are enforced on them when they seek debt relief or rescheduling through donor agencies.

The above two schools of development framework fit well in the analysis of tourism policies of Nepal because in the last two decades Nepali tourism policies have been written directly and indirectly by its international development partners. Nepal's external aid represented about 20 percent of the national budget in 2014-15 and most development expenditure is financed by the resource which comes largely from these partners, namely the Asian Development Bank, the World Bank and International Monetary Fund (Ministry of Finance, 2015). These agencies impose considerable conditions to the recipient countries; for example, Nepal's first tourism policy was a result of the Asian Development Bank's loan condition to fund a major tourism infrastructure project in Nepal. The policy was written under the direct supervision of the Bank and fully embraced the principles of economic neo-liberalism. Similarly, a policy shift towards neo-structuralism was initiated in the late 1990s by Nepal's international development partners, led by UNDP as part of Nepal's commitment to achieving a Millennium Development Goal through tourism. The above engagement of international development agencies in Nepal's tourism policy-making warrants a deeper analysis of tourism policy in order to see the underpinning development ideologies advanced by these agencies. 
Thus, this paper examines two tourism policies of Nepal that were formulated at the time when international development discourse was different. Jenkins (2015) mentions that over the past two decades the role of international development agencies in tourism policy and plans formulation has significantly increased. In the late 1980s, Nepal adopted neo-liberalism as an economic policy and later formulated its first tourism policy embracing the principles of economic liberalisation. However, this was short-lived when the domestic political environment changed and international development debates started to adopt the tone of neostructuralism. Nepal started deliberations on a new policy in the late 1990s and finally adopted a new policy in 2008 as an attempt to fine-tune its tourism policy to match the changed polity context (MoTCA, 2008). Since the development thinking that drives the development agencies itself has undergone a huge transformation in the last 25 years, it would be interesting to see how such changes are reflected in the tourism public policy of an aid-recipient country. The aim of this paper is to examine how changing development ideology has influenced the policy direction of Nepal's tourism.

Understanding a contextualised study of policy analysis can feed governments, tourism practitioners and other cognitive disciplines in a variety of ways. Richter (1989: 11) identifies that success or failure of tourism is the function of political and administrative action and as such it must come primarily from government leadership. Analysis of policy study can help governments to understand a wide range of tools that they can expedite for international tourism and their political and economic repercussions; it can shed light on ways in which international tourism can affect government interests and feed that knowledge into the political system (Hall and Jenkins, 1995). For practitioners, it can help them appreciate that 'tourism policy cannot be compartmentalised, adopted, and implemented in a vacuum' (Richter, 1989: 180); and that it cannot be 'independent of the political process and cannot be value free' (Hall and Jenkins: 3). For example, Nyaupane and Timothy (2010) have shown how the tourism policy of Bhutan is more related to power and regional politics than sustainable development. Thus, study of public policy can also help those working within the boundaries of many other disciplines such as geography, economics, and sociology to comprehend the policy process and identify sources of power in tourism policy-making. 
The paper makes some valuable contributions to existing literature. First, it provides empirical evidence from comparative study of Nepal's two tourism policies to show that there is a strong link between international development ideology and tourism policy change in Nepal. It shows that in the context of developing countries, seemingly 'tourism' policies are the outcome of domestic political contexts: that they are not outwith the scope of international development ideology advanced by its development partners. Second, it identifies that ideological change can have a great bearing on tourism bodies' ability to perform, particularly on the institutions that are established on a different ideological premise and are not adaptive to change, and suggests tourism managers must be deft at comprehending the larger context under which policy change takes place and be receptive to change to maintain their relevancy.

\section{Ideological questions in tourism policies}

There is limited literature on development ideology in tourism policy study. Most studies are either on political ideology or political economy (Dieke, 1991; Airey and Chong, 2010; Bramwell and Lane, 2010, 2012; Nunkoo and Smith, 2013; Chheang, 2008; Altinay and Bowen, 2006; Hall, 2010; Wan, 2013). The political economy approach lays emphasis on the studies of governance and often focuses on changes in the roles and capacities of government: what drives the changing roles and strategies of government, including in the wider institutional and political setting (Zhang, Chong and Ap, 1999; Nyaupane and Timothy, 2010; Dieke, 1991; Chambers and Airey, 2001; Cantallops, 2004) and the subject of development theory is not adequately discussed. One of the reasons for this is emphasis on the values of neo-liberalism in tourism policy study since the 1980s (Bramwell, 2006; Dredge and Jenkins, 2013; Dredge and Jamal, 2015). Such studies have led to the view that there is a distancing of government from direct policy interventions and the role of the state in recent years has had a diminishing capacity to directly lead in public policies (Wan and Bramwell, 2015); as a result governance and community has remained their main focus. Their main point is that the welfare mode of the government has become less relevant for tourism destinations (Gill and Williams, 2011).

Other studies are concerned with politics or political change (Hall, 1994; Pforr, 2008). From a political perspective, the nature of state involvement in tourism is dependent on both the political and economic structures and the prevailing political ideology in the destination state 
(Sharpley and Knight, 2009; Elliot, 1997; Chambers and Airey, 2001; Bramwell and Meyer, 2007; Krutwaysho and Bramwell, 2010), though the political-economic relationship of one nation with another or with the wider international community may represent significant influence on tourism development. Richter (1989: 8) has made a very useful note of the role of tourism in international relations as a means of initiating or enlarging the scope of international cooperation. Her contention has been that in the international arena, where most relations between nations have a political component, it would be naïve to assume that tourism development would not have strong political implications. However, studies looking into the aspects of international cooperation and interventions in tourism policy are still very limited. Existing studies of international agencies' engagement relate to offering expertise in design and development of specific tourism projects (Telfer and Sharpley, 2008; Hawkins and Mann, 2007). Commenting on the World Bank's involvement in tourism, Hawkins and Mann (2007) mention that there has been a shift to a more micro-level and policy intervention targeted at outcomes such as improving the livelihoods of local people. However, studies of the ideological context under which such interventions take place are still very scant.

For most tourism scholars, economic concerns were principal in tourism traditionally (Baum, 1994; Dredge and Jamal, 2015; Edgell, 1990). However, governments' roles in the sector have extended beyond economic considerations to address the environmental and social consequences of development (Nunko and Smith (2013). There are a number of cases where policies have been driven by such thinking (Wang and Bramwell, 2012; Webster, Ivanov, and Illum, 2011; Ruhanen, 2013). Ruhanen (2013) argues that the diffusion of the sustainable development concept in the 1980 s has led governments to assume greater roles and responsibilities in tourism planning. Since planning is largely a political process, in order to gain political support for tourism development governments now usually attempt to secure a balance between economic priorities, the environment, and the local society (Bramwell, 2011). Bramwell (2011) further suggests that a politically stable relationship between the state and its citizens is important to maintain political legitimacy and effective authority (Purcell and Nevins, 2005) and to ensure the state's ability to reflect the popular will (Bramwell, 2011). These studies suggest that neo-structural principles have great relevance because of the changing role of tourism; however, none of the above studies make a link between development ideology and the changing nature of tourism policies. 
Burns (2004) has tried to deal with this ideological issue by looking into the two contradictory ends of a planning spectrum: Tourism First and Development First approaches, both of whom have close resemblance to the above two development ideologies. Much like neo-structuralism, the Development First school is concerned with economic and social dualism, core-periphery relationships, and concomitant underdevelopment; the Tourism First school with its key concerns about economic growth relies on 'trickle down' or multipliers for development which resembles the principles of neo-liberalism. Though Burns' discussion identifies the flaws and patterns of bipolarities between the two approaches and broadens the debate to an extent, his paper is conceptual and does not provide empirical evidence to show the nature and actors involved in ideological influences in the tourism development process.

\section{Research context}

The institutionalisation of tourism in Nepal had begun in 1962, when the government started to keep records of incoming visitors which stood at 6000 that year. Earlier, the successful ascent of Mt. Everest in 1953 gave Nepal unprecedented media attention that helped realise the country's tourism potential. Nepal began to implement the structural adjustment programme of the International Monetary Fund (IMF), and the World Bank (WB) in the mid-1980s during the declining phase of absolute monarchy. In 1990, a significant political change took place and Nepal adopted constitutional monarchy, ending three decades of the old autocratic regime of absolute monarchy. The new Nepali regime embraced neoliberal policies more vigorously. This also brought about important changes in tourism policies and a new tourism policy was drafted, which opened a myriad of opportunities and tourism made significant growth until 1999, the year that saw half a million visitors. However, as argued by Ocampo, Griffith-Jones, Noman, Ortiz, Vallejo and Tyson (2010) the structural reforms failed to make a significant mark in other economic and social development and as a result a serious armed conflict broke out in 1996 (Sharma, 2006: 1248). With a view to reducing poverty to address people's unrest and agitation, Nepal began to implement a Poverty Reduction and Growth Facility Programme with the IMF and Poverty Reduction Support Credit with the WB in 2003. This was a major policy change from the neoliberal principles to a neo-structural approach, which was adjusted in Nepal with a new Tourism Policy in 2008 that enshrined neo-structural values. 
According to the Ministry of Culture, Tourism and Civil Aviation, Nepal received 800,000 international visitors in 2014 (MoTCA, 2015). India (17\%) and China (15\%) are the main source markets followed by the US, Sri-Lanka and the UK. The principal reasons for visits are holiday (50\%), pilgrimage (13\%) and trekking \& mountaineering (12\%). Tourism is highly seasonal and is spread around February-April and September-November. According to the World Travel and Tourism Council (WTTC, 2015), the direct contribution of tourism to Nepal's GDP in 2014 was 4.3\%. This primarily reflects the economic activity generated by industries such as hotels, travel agents, airlines and other passenger transportation services and includes the activities of the restaurant and leisure industries directly supported by tourism. This contribution is expected to grow to $4.4 \%$ by 2025 . Tourism generated half a million jobs in 2014 and is expected to grow at a yearly rate of $3.0 \%$ over the next ten years. However, the above targets for Nepal are likely to be affected in the coming years because of the deadly earthquake of April 2015. The quake damaged many of its UNESCO enlisted World Heritage Sites and some trekking routes and as a result, according to the Department of Immigration, the total arrivals in 2015 fell to a six-year low of over half a million (TKP, 2016).

\section{Research method}

This paper is driven by the following research question: Does the change in development discourse play a role in shaping the tourism policy of a developing country? The study adopted a qualitative approach as it was believed that tourism policy-making is a social activity where various actors, institutions, groups, organisations, and individuals engage and influence perceptions of policies (Bramwell and Lane, 1999). Such public policy requires the policy researcher to analyse numerous decisions made by many different individuals, and actions that have often been shaped by earlier policies and may be linked with other seemingly unrelated decisions (Wray, 2009). Thus, a comparative study of two tourism policies marked by two distinctive political environments both internally and externally would be helpful to widen our understanding of tourism policy-making.

Two policies were studied using the idiographic approach. This approach focuses on the interplay of factors that might be quite specific to the individual settings, and though the two settings might share some aspects in common, these will inevitably be materially affected by other differences between them (Gibbs, 2010). Each of the two policies studied was taken as 
a specific case, as they shared common institutions and actors at home; there was a large variation in terms of domestic political change and a significant change in the international environment. The study appreciates that government involvement in tourism can happen formally through tourism policies but it may also be indirect, whereby government actions influence tourism as a by-product of an interest in some related areas (Airey, 1983). As such, all major government actions related to achieving the policy goals from 1990-2015 were extensively considered in the study.

Primary data was collected through the documentary study of the content of the two tourism policies and archival records of various tourism-related regulations since the 1990s. Additionally a total of 18 interviews with key tourism individuals were conducted during August 2015-July 2016. The interviews included former Secretaries and Director Generals at the Ministry of Culture, Tourism and Civil Aviation, former and existing Chief Executive Officers of the Nepal Tourism Board, tourism entrepreneurs, and tourism officials at the tourism ministry and Nepal Tourism Board. The respondents were purposefully chosen as they were 'information rich' actors because of their positions, involvement in key policy processes, and reputations as influential and 'informed' insiders (see Bramwell and Meyer, 2007). These individuals were identified from the researcher's own long engagement with Nepal's tourism industry, reports in the media and other documents, and from snowball suggestions made by respondents who were contacted during the early stage of the study. Interviews largely concerned policy measures in tourism since 1990 and lasted between 4560 minutes. Secondary data were collected through various sources: government policies of Nepal; periodic planning documents from the National Planning Commission; various directives and notices of the Ministry of Culture, Tourism and Civil Aviation; the Nepal Tourism Board Annual Operation Plans, marketing strategy documents, 2020 tourism vision strategies, press releases and media sources. The form, structure, and content of the secondary documents were carefully studied as they often manifest the ideologies of their organisations and the findings were checked against interview data for correlations and verifications (O’Brien, 2010).

The interview data were first transcribed into text by word-processing. The transcription was done selectively, considering the data's contribution to the research question. Some researchers advocate analysing texts without transcribing them as this allows researchers to 
focus on the bigger picture and not get bogged down in the details of what people have said (Gibbs, 2010). Thus, in some cases, data were analysed directly from the interview. Interview transcripts and secondary documents were thematically analysed, for which the data were selectively coded, looking for themes to emerge. In selective coding, researchers look selectively for the cases which illustrate themes and make comparisons and contrasts after most or all data collection is complete (Neuman, 2003). Each emergent theme was later organised into and presented as a sub-heading in the findings section.

Scholars argue that studies of tourism policy should try to avoid attempting universal models and consider using thick description to improve the understanding of policy in a specific context (Hall and Jenkins, 1995; Jafari, 1989; Kerr, Barron and Wood, 2001). Such an approach can consider the wider political context within which decisions are made (Stevenson, Airey and Miller, 2008). However, an important aspect of such descriptive study is that the researcher's ideological beliefs and values may play a part in directing or constraining the information sources, methodology, analysis and findings (Hall and Jenkins, 1995). The researcher is a Nepali tourism scholar and has nearly a decade's experience of working on the Nepali Tourism Board. This had a number of advantages in terms of accessing data, identifying potential sources of information and cross-checking the validity of information and verifying with alternative sources. Another advantage is that the researcher can bring a local perspective to the interpretation which is important in the context of Nepal, where the hegemony of western discourse dominates the narratives in almost every sphere of scholarship.

\section{Findings}

\section{Background to tourism policy reforms in the 1990s}

The international context in 1990s was marked by the rise of economic neo-liberalism and the formal adoption of the Washington Consensus. The post-1990 Nepali government showed considerable commitment to neo-liberal policy and the government negotiated a loan agreement with the Asian Development Bank in 1996 for the development of tourism infrastructure. The ADB loan was used for developing and upgrading new and existing airports, including the upgrading of the capacity of the international airport in Kathmandu and building two Tourist Service Centres, one each in Kathmandu and Pokhara. The ADB loan had a precondition that the government would further liberalise the tourism sector, 
'The borrower shall ensure that the Nepal Tourism Board will be established, in terms of the Tourism Policy, to replace DOT (Department of Tourism). The borrower shall consult with the Bank with respect to the draft rules and regulations of the Nepal Tourism Board prior to its enactment. The Nepal Tourism Board shall comprise representatives of the Borrower and the private sector and shall be an autonomous organisation responsible for the coordination of all tourism sector development, including project planning, funding and implementation'. (ADB, 2005, the agreement was originally signed in 1996)

\section{State role reduced, private encouraged}

In order to get neo-liberalism embedded in Nepal's tourism planning, a new Tourism Policy and National Civil Aviation Policy were prepared in consultation with development agencies and the private sector to reflect the changed priorities (MacLellan, Dieke and Thapa, 2000). The new tourism policy was aimed at achieving 'policy integration', where a particular policy and the values on which it is based is integrated into a broader and holistic set of policies (Humphreys, 2016: 436). The new tourism policy enshrined very strong private sector sentiment which was visible in the preamble which stated,

'...The tourism policy has been formulated with the aims to increase national productivity and income, to increase foreign currency earnings, create employment opportunities, improve regional imbalances and project the image of Nepal more assertively in the international areas, through the development and diversification of the travel and tourism industries.' (MoTCA, 1995)

A former secretary at the Ministry of Tourism noted that, 'the main stance of the new policy was the recognition that tourism is a driver of economic growth' (R10). According to him, 'the private sector was encouraged to lead the industry by gradually minimising the state's direct involvement in tourism'. The finance minister who led the liberal project repeatedly reiterated that the role of the state is simply to provide social goods such as infrastructure and education and to regulate the market in such a way that the entrepreneurial capacities of the people are allowed to flourish (Mahat, 2005). To achieve the objectives of the free market economy, the policy proposed, 'The Department of Tourism will be abolished... responsibilities like formulation and implementation of tourism programmes, tourism promotion, infrastructure development, extension of tourist service and facilities, human 
resource development and environment conservation are handed over to the Board (i.e. the Nepal Tourism Board), registration regulation and facilitation of the travel and tourism industries will be carried out by MOTCA.' (MoTCA, 1995)

The new policy generated significant interest in tourism investment from the private sector. The government approved two five-star hotels and a cable car project without delay. Permits for new casinos were issued to the private sector. Similarly, private investors were allowed to open lodges inside the national parks earlier restricted exclusively to the elite royal families. The above advances in tourism planning and management and improvements in legislation were followed by promotional campaigns to attract visitors and tourism investment to the country. The year 1998 was declared as the 'Visit Nepal Year 1998'. The campaign encouraged foreign investment in the tourism sector, state controls were gradually removed and no permits were required for trekking in rural areas. Most regions of the country were opened to tourists, with a few exceptions pertaining to some restricted areas, for which a special entrance permit was required. The country adopted a liberal-sky policy and the Nepali airspace was opened for private airlines, ending the four decades of state airliner monopoly. An important point to note here was that even the principal opposition party who formed a minority government in 1994 for the most part accepted the neo-liberal world context, despite their Communist background (Hachhethu, 2002: 228).

In order to implement the new policy, a donor-funded project let by UNDP prepared the groundwork for the establishment of the Nepal Tourism Board (NTB) and the NTB Act was passed by the Parliament in 1997, becoming fully functional from January 1999. NTB was designed as a partnership between the private sector and government, with the majority of private sector representatives, nominated by the government, forming the executive committee. The Board was funded by levying a 2 per cent tourist service fee on every service catered for by tourism service providers, which was instrumental in bringing greater engagement of the private sector in the management and marketing of Nepalese tourism. According to one respondent (R12), such a strong emphasis on the private sector was informed by a belief in Western countries that tourism is a business, or economics, and should be best left to the industry. Still, there is a flaw with this 'tourism as industry' perspective because such an approach is positivist and would mean destinations can secure a competitive edge in increasingly global consumer market (Ritchie and Crouch, 1993; 
Bramwell and Lane, 2012). However, the reason for such an approach can be attributed to the fact that politics is relatively stable and parties are ideologically close in the West and as such tourism policy is studied under the wider context of political economy.

Public-private partnership (PPP) has been considered the 'Trojan Horse' of neoliberal ideology (Miraftab, 2004). It is celebrated by international development agencies as a key strategy for neo-liberals, who want less of a role for government and more for the private sector on the grounds that government is inefficient (Savas, 2000); it is invoked in the phraseology of a government-led and private sector-driven tourism industry (Giampiccoli, 2007: 184). In tourism there have been some excellent examples of public-private partnerships in recent years. For example, a report produced by UNWTO in collaboration with the SNV Netherlands Development Organization highlighted the positive outcomes of nine partnerships in Ghana, Costa Rica, and Bhutan (WTO, 2015). The report demonstrated ways in which partnerships can widen contacts and strengthen communities, link components within the tourism value chain, improve the marketability of tourism initiatives, and ensure inclusiveness and equity.

A respondent (R15) confirmed that the UNDP project took a considerable time in designing the structure of the Board, though, he admitted, it did not spent equal time on the equity dimension of the partnership. According to Miraftab (2004), this is common in the case of PPP discussion. He argues that the literature on PPP is dominated by mechanistic accounts of PPP and the question of the political, economic, social, and cultural environments of PPPs and whether they do serve the interests of the poor is very thinly treated (Osbourne, 2000; Linder, 1999; Hall, 2007). This was reflected in the working of the Board as well. For example, a respondent (R17) mentioned that for the first 3 years of its establishment the Board did not have any priorities or programmes on the domestic front of tourism and no thought was given to product diversification or tourism's contribution to the local economy.

\section{Beginning of the end of neo-liberal policies}

Scholars believe that state and individual ideologies do influence the pattern of tourism development (William and Shaw, 1988). By the beginning of the new millennium, the attempt to destabilise the new economic basis in Nepal had already begun, which brought instability to national politics and coalitions started to become the norm. The tourism ministry 
began to come under the control of leftist parties for whom the neo-structural approach was more appealing; as a result the role of the private sector in the NTB started to diminish in three ways: first, in 2005, without proper consultation with the industry, the NTB's revenue system was changed, whereby tourists were required to pay $\$ 5$ on departure from the international airport. The new revenue arrangements increased the NTB's revenue five-fold; however, it significantly removed the engagement of private industry in the Board. Second, the appointment of the NTB executive committee members from the private sector quota was largely abused by tourism ministers because of party politics: party favourites rather than genuine entrepreneurs were appointed to the NTB executive committee. Third, the previously revoked trekking permit was reinstated as the Trekkers Registration Certificate in 2006. This required all trekkers to obtain a certificate from the trekking agents association, creating polarisation between trekking agents, who favoured strong state protection for their industry as trekking was still protected from foreign investment, and the other tourism sectors who were proponents of a free market economy.

\section{Background to tourism policy reforms in the 2000s}

The groundwork for the 2008 policy had already been laid in the late 1990s when there began a growing discourse that socio-economic disparity was created by neo-liberal policies. The Maoists party pursued the above line of argument, and as in other countries (see Murtagh and Shirlow, 2012), they followed the sectarian politics of blaming the neo-liberalists or the political 'other' for failure to deliver to the deprived and marginalised groups. As a reaction to this, international development agencies, the UNDP, DFID and SNV came together to fund a social development project with the title the 'Tourism for Rural Poverty Alleviation Programme' (TRPAP). The project approached tourism as a development practice (see Hummel and van der Duim, 2016) and had noble objectives to help achieve the targets set by Millennium Development Goals and complement the values of neo-structural principles. For example, one of the tasks of the TRPAP project was '...to contribute to the poverty alleviation objective of the government through review and formulation of policy and strategic planning for sustainable tourism development, which are pro-poor, pro-environment, pro-women and pro-rural communities' (TRPAP, 2006). The project engaged extensively with local communities and state agencies, largely overlooking the private sector industry. As part of its objectives to review existing rules and regulations on tourism, the project also prepared the groundwork for a new tourism policy. A former member of TRPAP project 
management team (R11) said the following about their involvement in drafting the new policy,

'We were very much involved in the final preparation of the policy. We read line to line and provided our feedback. $90 \%$ of our feedback was incorporated. However, our aim was to name it a pro-poor tourism policy which unfortunately did not happen.'

The evolution of pro-poor tourism is linked with the idea of the neo-structural model. According to Murray and Overton (2011), the adaptation of the Millennium Development Goals (MDG) in 2000 was a highly significant development for neo-structuralism. The MDG appeared to have a lot in common with the neo-structural approach in terms of promoting balanced and broad-based development where equity and environment were considered of equal importance to economic growth. The MDG crystallised a new approach to aid that redefined its overt objective: the elimination of poverty on a global scale (de Haan, 2009). This new approach to aid attempted to bring development more into line with the MDG and tourism was adopted in a number of developing countries' PRSPs, including those not readily associated with tourism such as Bangladesh or Sierra Leone (Telfer and Sharpley, 2008). For this reason the idea of pro-poor tourism was advanced which made explicit reference to the potential of tourism for eradicating poverty (Goodwin 2002; Hall and Brown, 2006; Harrison and Schipani, 2007; Hummel and van der Duim, 2012; Schilcher, 2007). The TRPAP project was specially designed to meet the above objectives. A respondent (R11) confirmed that even the NTB reluctantly took the responsibility for the improvement of existing products and the development of new ones in order to diversify tourism activities in the country in later years. Internationally, there was a decline in the neo-liberal economy of western countries and the imminent financial crisis was looming.

However, the development ideology that vouched for the increasing role of the state helped advance the agenda of the neo-structural approach in Nepal because this resonated well with the leadership at the tourism ministry, which had a minister from the Maoist Communist party at that time, in the opinion of a respondent (R9). Interestingly, some of the stances of neo-structuralism are similar to the agenda advanced by Nepali Maoists. For example, according to Kay (2006), neo-structuralists emphasise the need for enhancing equity and citizenship through three goals: i) minimise the proportions of people whose living conditions 
are below an acceptable standard; ii) ensure progressive abolition of discrimination due to social, ethnic and gender differences, and iii) lament that globalisation and neo-liberalism have eroded social cohesion and solidarity.

The Maoist influence in the policy was visible because, according to a respondent (R9), the purpose of the new tourism policy was to provide a feel for the political change of 2008 that abolished monarchy and brought the Maoist party to power. This is acknowledged in the policy in the following ways, 'Subsequent to the ten years' long people's war and historical popular movement... recognising the necessity of tourism promotion for economic change, the Government of Nepal has ...declared to frame a new tourism policy...'(MoTCA, 2008). According to another respondent (R7), the aftermath of the new policy and ideological priority given to it was visible in one of Nepal's prominent places for wildlife tourism. A conflict broke out in Chitwan in July 2009 when the new government did not renew the operating licence of seven eco-lodges before their term expired in 2009. Most of these ecolodges were permitted to open inside the park in the early 1990s as part of the government's neo-liberal policy. According to respondent (R7), the closure of these private eco-lodges was an example of the government's policy departure from neo-liberal principles (also see Bhandari, 2012).

\section{Private role reduced, state encouraged}

Scott (2010) argues that tourism policy represents the aims and roles that the government wants tourism to achieve. According to him, the aims of the policy can be associated with economic development, social equity and pro-poor tourism, employment and quality, visitor fulfilment, community wellbeing, cultural richness or environmental sustainability and much more. A respondent (R11) stated, 'the purpose of the new policy of 2008 was, partly, mobilising tourism to achieve social equity and community wellbeing'. This is evidenced in the high priority given to small scale community-led tourism activities as delivered through village tourism and homestay tourism. The policy states, '(T)his will develop ownership by the local community especially in the area of rural tourism and competitiveness in quality services' (MoTCA, 2008). A brand new Homestay Operations Directive (MoTCA, 2010) was formulated, 'in accordance with the objectives of increasing rural employment and lifestyle of rural underprivileged, women, Madheshi, ethnic minorities and other marginalised groups who have not been included in the development process enshrined in Tourism Policy 
the homestay intends to capture that essence.' According to a respondent (R10), such language of the directive correlates with the Maoist party's election manifesto that made the advancement of the underprivileged class or the 'proletariat' its main goal. Interestingly, one respondent (R12) opined that the idea of homestay connects very well with the Maoist philosophy that advocates using people as a tool for revolution. Making the connection between the two ideologies, he argued that Maoism views the industrial-rural divide as a major division exploited by capitalism, identifying capitalism as involving industrial urban developed 'First World' societies ruling over rural developing 'Third World' societies. It identifies peasant insurgencies in particular national contexts as part of a context of world revolution, in which the global countryside would overwhelm the global cities. For Maoists villages and rural areas are the focus of their strategy and the idea of homestay in the rural community connects strongly with their own idea of revolution.

This could be the reason that there were no deliberations on the potential threat that homestay can bring to local culture or peoples' way of life. There are number of studies that have shown the impact of tourism on host communities and their implications (Buzinde and Santos, 2009; Jackson and Inbakaran, 2006; Lepp, 2008; Ryan and Cave, 2005). However, the Homestay Operation Directive, 2010 does not identify or discuss any of the possible implications of the negative impact of this type of tourism.

International developments further strengthened the ground for a state-led policy. By 2010, the US and UK governments were bailing out a variety of firms, incurring large financial obligations by either committing or spending trillions of dollars in loans, asset purchases, guarantees, and direct spending. In line with such practice, the Maoist government decided to provide a guarantee for purchasing two aircraft for the state-owned airline, which was able to secure a \$106 million loan from Nepal's Employees Provident Fund to purchase two Airbus aircraft (Gurung, 2013). This was despite the fact that the airline was performing badly making most of its revenue not from flying, but from ground handling (TKP, 2011).

\section{Implications of policy change in tourism administration}

The biggest effect of policy change has been in the structure of tourism administration. Since 2008 the Department of Tourism has been re-established and is now running in parallel with the NTB. The ADB, that asked the government to dissolve the Department of Tourism as 
part of its loan conditionality in early 1990s, did not comment when the Department was reestablished. Loan conditionality has been a common feature of international organizations and bilateral donors have often tied financial assistance to the undertaking of political and economic reforms. The issue of whether conditionality is effective in achieving development goals has occupied centre stage in the development debate (Collingwood 2003), and studies have shown that the influence has been different in different countries, though there is an admission that the lending institutions have paid scant attention to the impact of their economic reform loans on vulnerable people (Alexander, 2001). A respondent (R14) took the view that the ADB's silence in the above case is an example of their indifference. Though it can be debated whether lending agencies should intervene in policy changes and even if the answer is yes, how long they should continue to intervene. It is thus morally indefensible to attach political conditions to financial assistance, an issue that has largely been taken for granted (Collingwood 2003).

A respondent (R13) complained that since the re-establishment of the Department of Tourism, the NTB has gradually been made dysfunctional by not appointing a chief for four years. The NTB's top officials have been suspended on charges of corruption and for a long period the organisation was run by government bureaucrats until a CEO was appointed in December 2015. A respondent (R5) long associated with the NTB said, 'The appointment of a government bureaucrat as head of the NTB is a back door entry to institutionalise state control over NTB resources, as this is done through wrong interpretation of NTB acts and regulation'. Some respondents (R15, R11) believed that the recent appointment of a junior employee at the board as its CEO is also an attempt to weaken the institution. However, the appointment was based on free competition and many other respondents (R10, R18, R6) took the view that having a young leadership will contribute towards institutionalisation of the Board.

The above remarks indicate that the implications of the ideological change in policy has raised an ideological dilemma for managers of the NTB in two ways. First, despite such an ideological difference in the two policies, many respondents do not see the link between neostructural principles, the new tourism policy and increasing state control. A senior NTB member of staff believed that tourism policies and priorities are 'an act of whims and fancies of the ministerial ruler' (R15). Such an understanding does not fully comprehend the 
changed policy context and is likely to invite conflict between the Board and the tourism ministry as tourism managers are convinced that the state should not intervene in what they regard as the NTB's mandate. This is not surprising because the organisational culture of the Board is based on neo-liberal principles and it maintains the strong service orientation of the private sector, as the Executive Committee has private sector majority. However, if the new policy is to be successful, the Board must learn and adapt to the conditions of a changed policy environment by acknowledging the state as an important partner in tourism and internalise the changed policy context in its organisational structures. The Board must be adaptive and be prepared to make incremental adjustment as a result of environmental changes, goal structure changes, or other changes (Fiol and Lyles, 1985).

The second dilemma is that the increasing state control over the NTB has led the private sector to see the Board as a government institution, whereas the Board sees itself as a private sector body. For example, in 2014, private sector entrepreneurs agitated against the Board, demanding the removal of its chief, a probe into financial irregularities and disclosure of financial details of expenses amongst other demands. A respondent (R6) said, 'they could have done all of these themselves, as the Board is a private sector-dominated body.' He further stated that such an anomaly in understanding has severely impacted the functioning of the Board because the private sector does not always take ownership of the Board's activities and the government does not see it as one of its agencies.

This is also a major policy quandary. On one hand there is the demand for less government interference in the market and allowing industries to develop and trade without government assistance, while on the other hand industry interest groups still seek to have government policy developed in their favour, including the maintenance of government funding for promotion and development (Hall, 2010). Additionally, the post-conflict political scenario in Nepal makes change and transformation difficult to institutionalise as the social, emotional and political forces at play do not always allow it (Cook and Yanow, 1993). The problem with change management is difficult in Nepal because stakeholder consultation seldom happens as it should. Hardly any consultation was done while drafting the new policy or changing the NTB's revenue structure. A multi-layered policy interaction could be helpful as organisational, community and individual learning are strongly interlinked and must be viewed in the context of each other (Marsick and Waitkins, 1999). 


\section{Conclusions}

This paper has examined and discussed how tourism policy in Nepal has been part of an approach to development that originated outside Nepal. The paper has shown that the tourism policies of Nepal were formulated in an effort to respond to an internal stimulant, that is, domestic political changes; however, the direction of the policies was largely shaped by ideological discourse directly and indirectly dictated by the international development agencies. The two tourism policies that enshrined the neo-liberal and neo-structural principles respectively took shape irrespective of the political ideologies of the political parties in power, suggesting that the country's huge dependency on external aid and development agencies cannot allow it to be totally independent in formulating its public policy. This challenges the view that the nature of state involvement in policies for tourism is dependent on political and economic structures and prevailing political ideology in the destination state (Sharpley and Knight, 2009: 242); on the contrary, the case of Nepal shows that international development partners and their economic ideologies can override the domestic political context.

Jenkins, Hall and Mkono (2014) are correct in stating that tourism policy scholarship has generally remained locked in examining the traditional models of governing and governance, and has yet to adequately embrace the policy implications of an increasingly globalised tourism system. This paper has suggested that the nature of policy interventions has depended on development ideology. For example, neoliberal ideology dictated in very heavy-handed ways what a recipient must do, and aid was used as a weapon to force structural reform and bring about market-led growth (Murray and Overton, 2011). The case of the Asian Development Bank's loan agreement that specified the condition that the Nepali government must show commitment to neo-liberal principles testifies to the above. However, the neostructural approach 'seemed to open the way for recipients to lead the process, establishing a welfare and poverty-focussed strategy that donors would fund substantially and without significant debate' (Murray and Overton, 2011: 314). As such no direct intervention was witnessed in the 2008 tourism policy. However, we must also take note that the neostructuralism approach chimes well with some of the values of the centre-left political groups who argue for greater state control over the economy. The predominance of tourism ministers 
from the centre-left parties was instrumental in institutionalising the neo-structural approach in tourism policy without much pressure from development partners.

This study points a number of lessons for other countries to learn from Nepal. It attests that the political-economic relationship of a developing country with its wider international development community may exert a significant influence on its tourism policy (see O'Brien, 2010). It would be helpful for tourism planners to strive to achieve policy integration that fosters the coherency of national priorities and addresses the preferred direction outlined by their international partners. Tourism managers should also understand that policy change can bring philosophical change in the approach to development and may require a change in ideological orientation of the organisation responsible for implementing the policy. This suggests that under the changed policy regime, tourism organisations must be prepared to readjust their priorities, goals, policies and structures and accommodate the conditions of change.

Given the limited resources of the state, it is important for Nepali tourism managers to mobilise private and public sector in whatever way possible so that they both can play an important and constructive role in tourism development. Giddens' (1998) proposition of a 'Third Way' or pragmatic 'new middle' political process that advocates seeking private sector involvement while the state plays its part - capitalising on the strengths of the welfare state and optimising the role of the market economy - is probably a useful approach, and we have noticed that this is the direction that the neo-structural approach seems to be taking. According to Burns (2004) such an approach could help resolve social issues and as such the donor agencies should define their role in terms of 'human development'. However, some of the ideas of these approaches could contradict the very philosophy on which DMOs are created, for example, there is a mismatch between NTB's mandate and a neo-structural approach. In such a scenario, the compatibility between ideological change and organisational mandate is an important area for future research. 


\section{References}

Airey D (1983) European government approaches to tourism. Tourism Management, 4(4), 234244.

Airey D and Chong K (2010) National policy-makers for tourism in China. Annals of Tourism Research, 37(2), 295-314.

Alexander NC (2001) Paying for Education: How the World Bank and the International Monetary

Fund Influence Education in Developing Countries. Peabody Journal of Education, 76(3/4), $285-338$.

Altinay L and Bowen D (2006) Politics and tourism interface. The Case of Cyprus. Annals of Tourism Research, 33(4), 939-956.

Asian Development Bank (ADB) (2005) Completion Report: Nepal Second Tourism Infrastructure Development Project. Manilla: ADB

Baum T (1994) The development and implementation of national tourism policies. Tourism Management, 15(3), 185-192.

Bhandari K (2012) Tourism or Conservation? A controversy in Chitwan National Park, Nepal. In O. Maufaqir and P. Burns (Eds.) Tourism and Controversies (pp. 229-241), Wallingford: CABI.

Bitar S (1988) Neo-conservatism versus neo-structuralism in Latin America. , CEPAL Review, 34, 45-62.

Bramwell B (2006) Actors, Power and discourses of growth. Annals of Tourism Research, 33(4), 957-978.

Bramwell B (2011) Governance, the state and sustainable tourism: a political economy approach. Journal of Sustainable Tourism, 19 (4/5), 459-477.

Bramwell B and Lane B (1999) Collaborations and partnerships for sustainable tourism. Journal of Sustainable Tourism, 7(3/4), 179-181.

Bramwell B and Lane B (2010) Sustainable Tourism and the evolving roles of government planning. Journal of Sustainable Tourism, 18(1), 1-5.

Bramwell B and Lane B (2012) Tourism Governance: Critical Perspectives on Governance and Sustainability: London: Routledge.

Bramwell B and Meyer D (2007) Power and tourism policy relations in transition. Annals of Tourism Research, 34(3), 766-788.

Burns P M (2004) Tourism Planning: A third way? Annals of Tourism Research, 31 (1), 24-43. 
Buzinde CN and Santos CA (2009) Interpreting slavery tourism. Annals of Tourism Research, 36, $439-458$.

Cantallops AS (2004) Policies supporting sustainable tourism development in the Balearic Islands: The Ecotax. Anatolia, 15(1), 39-56.

Chambers D and Airey D (2001) Tourism Policy in Jamaica: A Tale of Two Governments. Current Issues in Tourism, 4 (2-4), 94-120.

Chheang V (2008) The political economy of tourism in Cambodia. Asia Pacific Journal of Tourism Research, 13(3), 281-297.

Collingwood V (2003) Assistance with Fewer Strings Attached. Ethics \& International Affairs, Volume 17 (1), 55-67.

Cook SDN and Yanow D (1993) Culture and Organisational Learning. Journal of Management Inquiry, 2(4), 373-390.

De Haan A (2009) How the aid industry works: An introduction to international development.

Bloomfield: Kumarian Press.

Dieke PUC (1991) Policies for Tourism Development in Kenya. Annals of Tourism Research, 18, 260-294.

Dredge D and Jamal T (2015) Progress in tourism planning and policy: A post-structural perspective on knowledge production. Tourism Management, 51, 285-297.

Dredge D and Jenkins J (2003a) Federal-State relations and tourism public policy, New South Wales, Australia. Current Issues in Tourism, 6(5), 415-443.

Dredge D and Jenkins J (2003b) Destination place identity and regional tourism policy. Tourism Geographies, 5(4), 383-407.

Dredge D and Jenkins J (2013) Australian, national tourism policies: Influences of reflexive and political modernisation. Tourism Planning and Development, 9(3), 231-251.

ECLAC (2002) Globalization and Development. Santiago: United Nations, Economic Commission for Latin America and the Caribbean.

Edgell DL (1990) International tourism policy. New York: Van Nostrand Reinhold.

Elliott J (1997) Tourism, Politics and Public Sector Management. London: Routledge.

Fiol CM and Lyles MA (1985) Organisational learning. The Academy of Management Review. 10(4), 803-813.

Getz D (2012) Events Studies: Theory, Research and Policy for Planned Events. London:

Routledge. 
Giampiccoli A (2007) Hegemony, Globalisation and Tourism Practices in Developing Countries. In PM Burns and M Novelli (Eds.) Tourism and Politics (175-191). London: Routledge.

Gibbs G (2010) Analyzing Qualitative Data. London: Sage.

Giddens A (1998) The Third Way: The Renewal of Social Democracy. Cambridge: Polity Press.

Gill AM and Williams OW (2011) Rethinking resort growth: understanding evolving governance strategies in Whistler, British Columbia. Journal of Sustainable Tourism, 19(4-5), 629-648.

Goodwin G (2002) Pro-poor tourism: a new approach for poverty alleviation. In World Tourism Organisation (ed.) Tourism: a catalyst for Sustainable Development in Africa. Madrid: WTO.

Gurung H (2013) Silver lining in the Nepali sky. Nepali Times. Available online:

http://himalaya.socanth.cam.ac.uk/collections/journals/nepalitimes/pdf/Nepali_Times_662.pd $\underline{\mathrm{f}}$

Hachhethu K (2002) Party building in Nepal: Organisation, Leadership and People, a comparative study of the Nepali Congress and the Communist Party of Nepal (Unified Marxist-Leninist). Kathmandu: Mandala Book Point.

Hall CM (1994) Tourism and Politics: Policy, Power and Place. Chichester: Wiley.

Hall CM (2007) Pro-Poor Tourism: Do "Tourism Exchanges Benefit Primarily the Countries of the South"? Current Issues in Tourism, 10(2\&3), 111 - 118.

Hall D and Brown F (2006) Tourism and Welfare: Ethics Responsibility and Sustained Wellbeing. Cabi: Wallingford.

Hall CM and Jenkins JM (1995) Tourism and Public Policy: Routledge.

Hall CM (2010) Politics and Tourism: Interdependency and Implications in Understanding Change. In R Butler and W Suntikul (Eds.) Tourism and Political Change (2-12). Oxford: Goodfellow publishers.

Harrison D and Schipani S (2007) Lao Tourism and Poverty Alleviation: Community-Based Tourism and the Private Sector. Current Issues in Tourism, 10(2/3), 194-230.

Harvey D (2005) A brief history of neoliberalism. Oxford: Oxford University Press.

Hawkins D and Mann S (2007) The World Bank's role in tourism development. Annals of Tourism Research, 34(2), 348-363.

Hummel J and van der Duim R (2012) Tourism and development at work: 15 years of tourism and poverty reduction within the SNV Netherlands Development Organisation. Journal of Sustainable Tourism, 20(3), 319-338. 
Hummel J and van der Duim R (2016) SNV's modes of ordering: Organising tourism as development practice. Tourism Management, 57, 312-322

Humphreys D (2016) Integers, integrants and normative vectors: The limitations of environmental policy integration under neo-liberalism. Environment and Planning C: Government and Policy, 34, 433-447.

Jackson MS and Inbakaran RJ (2006) Evaluating residents' attitudes and intentions to act towards tourism development in regional Victoria, Australia. International Journal of Tourism Research, 8(5), 355-366.

Jafari J (1989) An English-language literature review. In J Bystrzanowski (Ed.), Tourism as a factor of change: the sociocultural study (pp. 17-60). Vienna: Centre for Research and Documentation in Social Sciences.

Jenkins CL (2015) Tourism policy and planning for developing countries: some critical issues. Tourism Recreation Research, 40(2), 144-156.

Jenkins JM, Hall CM and Mkono M (2014) Tourism and Public Policy: Contemporary debates and future directions. In AA Lew, CM Hall and AM Williams (Eds.) The Wiley Blackwell Companion to Tourism (p. 542-555). Oxford: Wiley-Blackwell.

Kay C (2006) Rural poverty and development strategies in Latin America. Journal of Agrarian Change, 6(4), 455-508.

Kerr W BarronG and Wood RC (2001) Politics, Policy And Regional Tourism Administration: A Case Examination Of Scottish Area Tourist Board Funding. Tourism Management, 22, 649657.

Krutwaysho O and Bramwell B (2010) Tourism policy implementation and society. Annals of Tourism Research, 37 (3), 670-691.

Lepp A (2008) Attitudes towards initial tourism development in a community with no prior tourism experience: The case of Bigodi, Uganda. Journal of Sustainable Tourism, 16, 5-22.

Linder S (1999) Coming to terms with the public-private partnership: A grammar of multiple meaning. American Behavioural Scientist, 43(1), 35-51.

MacLellan LR, Dieke PUC and Thapa BK (2000) Mountain Tourism and Public Policy in Nepal, In PM Godde, MF Price and FM Zimmermann (Eds.), Tourism and Development in Mountain Regions. Wallingford, Oxford: CAB International, pp. 173 - 197.

Mahat RS (2005) In Defence of Democracy: Dynamics and Fault Lines of Nepal's Political Economy. New Delhi: Adroit Publishers. 
Marsick VJ and Watkins KE (1999) Facilitating learning organizations: Making learning count Aldershot: Gower

Ministry of Finance (2015) Development Cooperation Report FY 2013-14. Kathmandu: Government of Nepal.

Ministry of Tourism and Civil Aviation (MoTCA) (1995) Tourism Policy. Kathmandu: Department of Tourism.

Ministry of Tourism and Civil Aviation (MoTCA) (2008) Paryatan Niti, Retrieved from http://www.tourismdepartment.gov.np/acts-regulations

Ministry of Tourism and Civil Aviation (MoTCA) (2010) Homestay Karyabidhi, Retrieved from http://www.tourism.gov.np/pdf/Homstay-karyabidhi2067-3-27.pdf

Ministry of Culture, Tourism and Civil Aviation (MoTCA) (2015) Nepal Tourism Statistics(2014). Available Online:

http://www.tourism.gov.np/images/download/Nepal_Tourism_Statistics_2014_Integrated.pdf Miraftab F (2004) Public-Private Partnerships: The Trojan Horse of Neoliberal Development?. Journal of Planning Education and Research, 24, 89-101.

Murray WE and Overton JO (2011) Neoliberalism is dead, long live neoliberalism? Neostructuralism and the international aid regime of the 2000s. Progress in Development Studies, 4, 307-319.

Murray WE and Pastor R (2008) Growth with equity? Neostructuralism in Chile. In WE Murray and E Rabel (Eds.) Latin America today: Challenges, opportunityes and trans-Pacific perspectives. New Zealand Institute of International Affairs/Victoria institute for Links with Latin America.

Murtagh B and Shirlow P (2012) Devolution and the politics of development in Northern Ireland. Environment and Planning C: Government and Policy, 30, 46-61.

Neuman WL (2003) Social Research Methods: Qualitative and Quantitative Approaches. London: Pearson Education.

Nunkoo R and Smith SLJ (2013) Political economy of tourism: Trust in government actors, political support, and their determinants. Tourism Management, 36, 12-132.

Nyaupane GP and Timothy DJ (2010) Power, Regionalism and Tourism Policy in Bhutan. Annals of Tourism Research, 37(4), 969-988.

O’Brien A (2010) Beyond policy making: institutional regimes, the state and policy implementation in the Irish case. Current Issues in Tourism, 13 (6), 563-577. 
Ocampo JA, Griffith-Jones S, Noman A, Ortiz A, Vallejo J and Tyson J (2010) "The Great Recession and the Developing World." Paper presented at the conference on Development Cooperation in Times of Crisis and on Achieving the MDGs. 9-10 June, Madrid.

Osbourne S (2000) Public-private partnerships for public services: An international perspective. London: Routledge.

Pforr C (2008) Three lenses of analysis for the study of tourism public policy: a case from Northern Australia. Current Issues in Tourism, 8(4), 323-343.

Purcell M and Nevins J (2005) Pushing the boundary: State restructuring, state theory, and the case of US - Mexico border enforcement in the 1990s. Political Geography, 24(2), 211-235.

Ritchie B and Crouch G (1993) Competitiveness in international tourism : a framework for understanding and analysis. World Tourism Education and Research Centre: University of Calgary.

Richter LK (1989) The politics of tourism in Asia. Honululu: University of Hawaii Press.

Ruhanen L (2013) Local government: facilitator or inhibitor of sustainable tourism development?, Journal of Sustainable Tourism, 21 (1), 80-98.

Ryan C and Cave J (2005) Structuring destination image: A qualitative approach. Journal of Travel Research, 44(2), 143-150.

Savas ES (2000) Privatisation and public-private partnership. New York: Chatham House.

Schilcher D (2007) Growth versus equity: The continuum of pro-poor tourism and neoliberal governance. Current Issues in Tourism, 10(2\&3), 166-193.

Scott N (2010) Tourism Policy: a strategic review. Contemporary Tourism Reviews. Oxford: Goodfellow Publishers. Online available:http://www.goodfellowpublishers.com/free_files/fileTourismPolicy.pdf Sharma K (2006) 'The political economy of civil war in Nepal', World Development, 34(7): 123753.

Sharpley R and Knight M (2009) Tourism and the State in Cuba: From the past to the future. International jJournal of Tourism Research, 11, 241-254.

Stevenson N, Airey D and Miller G (2008) Tourism Policy Making: The Policymakers' Perspectives. Annals of Tourism Research, 35(3), 732-750.

Telfer DJ and Sharpley R (2008) Tourism and Development in the Developing World. London: Routledge. 
The Kathmandu Post (TKP) (2011) NAC making losses due to services to remote sectors.

Available Online: http://kathmandupost.ekantipur.com/printedition/news/2011-04-26/nacmaking-losses-due-to-services-to-remote-sectors.html

The Kathmandu Post (TKP) (2016) Arrivals hit 6-year low as quake, agitation take toll. Available Online: http://bit.ly/20ib9KPhttp://kathmandupost.ekantipur.com/news/2016-01-22/arrivalshit-6-year-low-as-quake-agitation-take-toll.html

Tourism for Rural Poverty Alleviation Programme (TRPAP) (2006) Final Evaluation Report. Kathmandu: UNDP.

World Tourism Organization (2015) Affiliate Members Global Reports, Volume eleven-

Public-Private Partnerships: Tourism Development. Madrid: UNWTO.

Wang Y and Bramwell B (2012) Heritage protection and tourism development priorities in Hangzhou, China: A political economy and governance perspective. Tourism Management, 33 (4), 988-998

Wan YKP (2013) A comparison of the governance of tourism planning in the two special administrative regions (SARs) of China - Hong Kong and Macao. Tourism Management, 36, 164-177.

Wan YKP and Bramwell B (2015) Political economy and the emergence of a hybrid mode of governance of tourism planning. Tourism Management, 50, 316-327.

Webster C, Ivanov S and Illum SF (2011) The paradigms of political economy and tourism policy: National tourism organisations and state policy. In J Mosedale (Ed.) Political economy of tourism: a critical perspective (55-73). London: Routledge.

Williams AM and Shaw G (1988) Tourism and Economic Development in Eastern Europe and the Soviet Union. London: Belhaven Press.

World Travel and Tourism Council (2015) Travel and Tourism Economic Impact 2015 Nepal. Available online:

https://www.wttc.org//media/files/reports/economic\%20impact\%20research/countries\%2020 15/nepal2015.pdf

Wray M (2009) Policy communities, networks and issue cycles in tourism destination systems. Journal of Sustainable Tourism, 17(6), 673-690.

Zhang HQ, Chong K and Ap J (1999) An analysis of tourism policy development in modern China. Tourism Management, 20, 471-485. 